\title{
Radioactive contaminated soil removal from the sites of the former Azgir nuclear test site
}

\author{
D. G. Gilmanov \& E. Z. Akhmetov \\ National Nuclear Centre of the Republic of Kazakhstan (NNC RK), \\ Institute of Nuclear Physics NNC RK, Kazakhstan
}

\begin{abstract}
The research and engineering operations performed to clean and remove radioactive contamination from the Azgir test site improved levels of radiation in and around the site. After the operations, the possibility of contamination of personnel and the local population from radiation doses in the soil that exceed maximal permissible values for radiation were eliminated.

Keywords: Azgir nuclear test site, underground nuclear explosions, radionuclides, underground cavities from nuclear explosion, radioactive wastes.
\end{abstract}

\section{Introduction}

At the present time there are problems as a result of controlled peaceful nuclear explosions in Kazakhstan, which include clean-up activities in the contaminated area where the nuclear explosions were conducted. A considerable amount of time has passed since the explosions were carried out. This report addresses problems such as the removal of contaminated soil from the former AZGIR test site in the west of Kazakhstan. The pilot research was carried out from 1964 to 1979 by means of underground nuclear explosions in the rock salt massifs of an underground cavity used for multifunctional storage near to Azgir in Atyrau oblast (250 km from Caspian Sea and $70 \mathrm{~km}$ from the Volga River) at the salt dome of East and West Azgir. Among 39 peaceful underground explosions conducted in Kazakhstan (Table 1, Figure 1) [1], 17 explosions (22 blasting charges with energy release in trinitrotoluol equivalent from $0.01-103 \mathrm{kt}$ ) were carried out at a depth of $160-1500 \mathrm{~m}$ at 10 sites of the Azgir test site (Table 2). The total activity of underground cavities is about $10^{6} \mathrm{Ci}[2,3]$. 


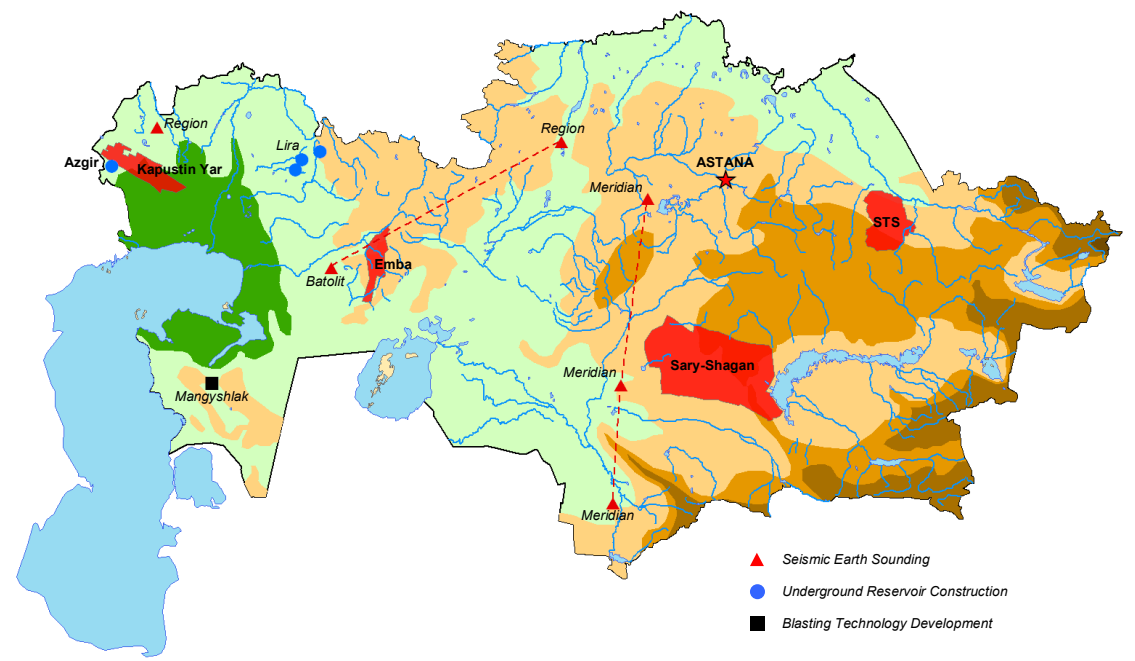

Figure 1: $\quad$ Peaceful nuclear explosions in Kazakhstan territory.

Table 1: Chronology of underground nuclear explosions at the Bolshoi Azgir salt dome.

\begin{tabular}{|l|l|c|c|}
\hline \multicolumn{1}{|c|}{ Site } & \multicolumn{1}{|c|}{ Explosion date } & $\begin{array}{c}\text { Depth } \\
\text { of charge } \\
\text { blasting, } \mathrm{m}\end{array}$ & $\begin{array}{c}\text { Explosion yield, } \\
\text { trinitrotoluol } \\
\text { equivalent, } \mathrm{kt}\end{array}$ \\
\hline A-I & April 22,1966 & 160 & 1.1 \\
\hline A-II & July 1,1968 & 600 & 27 \\
\hline A-III & December 22,1971 & 1000 & up to 64 \\
\hline A-IV & July 29,1976 & 1000 & up to 60 \\
\hline A-V & September 30,1977 & 1500 & up to 10 \\
\hline A-VII & October 17,1978 & 1000 & $0.001-20 ; 20-150$ \\
\hline A-IX & December 18,1978 & 900 & 103 \\
\hline A-VIII & January 17,1979 & 1000 & $0.001-20 ; 20-150$ \\
\hline A-XI & July 14,1979 & 1000 & 20 \\
\hline A-X & October 24,1979 & 1000 & $0.001-20 ; 20-150$ \\
\hline
\end{tabular}

As a result of the explosions conducted in the rock salt massif, 9 relatively resistant cavities of different volumes (from 10,000-240,000 $\mathrm{m}^{3}$ ) were formed over a period of 3 decades (Figures 2 and 3). All the explosions were projected as having been fully confined i.e. without radioactive products reaching the surface. However, this was not achieved, as shown by the data of radioactive discharge duration (having become the reason for the test site contamination) from cavities over a period of some days up to months and of its total activities up to $10^{18} \mathrm{~Bq}$. Site contamination also occurred as a result of some technological operations related to the opening of the cavity by means of additional boreholes, as well as radioactive gases with activity up to $10^{7} \mathrm{Ci}[4]$ that were injected into the atmosphere. Radioactive spots at the site were the source of secondary 
radioactive contamination of the environment (radionuclide transfer by way of wind and atmospheric fallout) and radiation risk to the public. Therefore the problem of the clearance of contaminated land was considered as current in terms of sanitary and ecological aspects.

Table 2: Peaceful nuclear explosions in Kazakhstan.

\begin{tabular}{|c|c|c|c|}
\hline $\begin{array}{l}\text { Date, } \\
\text { years }\end{array}$ & $\begin{array}{c}\text { Place } \\
\text { (oblast) }\end{array}$ & Condition & $\begin{array}{l}\text { Amount of } \\
\text { explosions }\end{array}$ \\
\hline 1966-1979 & Guryev & $\begin{array}{l}\text { Construction of underground tanks } \\
\text { of large volume in rock salt massif } \\
\text { (A-1-A-XI) }\end{array}$ & 17 \\
\hline $1969-1970$ & Mangyshlak & $\begin{array}{l}\text { Development of } \text { commercial } \\
\text { explosion technology. T-1, T-2, T-3 } \\
\text { boreholes }\end{array}$ & 3 \\
\hline 1965-1974 & $\begin{array}{l}\text { Semipalatinsk } \\
\text { Test Site }\end{array}$ & $\begin{array}{l}\text { Experimental works on NET } \\
\text { development in behalf of the national } \\
\text { economy }\end{array}$ & 7 \\
\hline 1972 & Ural & $\begin{array}{l}\text { Depth seismic "Region" sounding, } \\
\text { P-5 borehole }\end{array}$ & 1 \\
\hline 1972 & Kustanai & $\begin{array}{l}\text { Depth seismic "Region" sounding, } \\
\text { P-5 borehole }\end{array}$ & 1 \\
\hline 1973 & Turgai & $\begin{array}{l}\text { Depth seismic "Meridian" sounding, } \\
\text { MN-1 borehole }\end{array}$ & 1 \\
\hline 1973 & Shymkent & $\begin{array}{l}\text { Depth seismic "Meridian" sounding, } \\
\text { MN-2, MN-3 borehole }\end{array}$ & 2 \\
\hline $1983-1984$ & Ural & $\begin{array}{l}\text { Construction of underground cavities } \\
\text { "Lira" - } 1 \div 6\end{array}$ & 6 \\
\hline 1987 & Aktyubinsk & $\begin{array}{l}\text { Development of nuclear explosion } \\
\text { technology "Batolit", BT-2 borehole }\end{array}$ & 1 \\
\hline \multicolumn{3}{|r|}{ TOTAL } & 39 \\
\hline
\end{tabular}

Research and practical measures regarding the removal of radioactive contamination at the test site were carried out according to the following activities: mapping of the contaminated area, determination of radionuclide concentration in the soil, location and arrangement of radioactive soil disposal, cleansing of the area from radioactive contamination, transfer and burying of contaminated soil, dosimetry and determination of soil specific activity at the contaminated site, refilling of excavation with pure soil, estimation of mass and total activity of removed soil.

Radionuclide concentrations, especially Cs-137, as the concentration of other radionuclides were comparatively low (at the level of natural background and global fallout), allowed to subsume excavated soil (with maximal specific activity up to $9000 \mathrm{~Bq} / \mathrm{kg}$ ) to the category of low-level radioactive wastes with established intervention level $-10^{4} \mathrm{~Bq} / \mathrm{kg}$ and more by Radiation Safety Standards in Kazakhstan. Under this approach specified soil just had to be removed to a nearby ground disposal location at a depth of $10 \mathrm{~m}$. 
722 Management of Natural Resources, Sustainable Development and Ecological Hazards
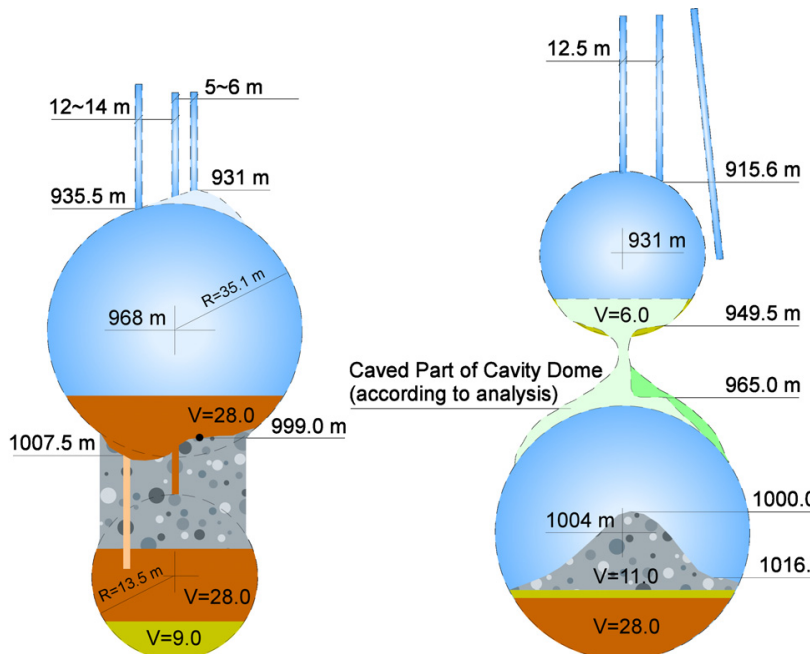

Caved Part of Cavity Dome
(according to analysis)

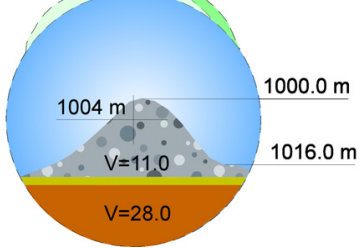

Figure 2: $\quad$ Cavity scheme A-VII and A-VIII.

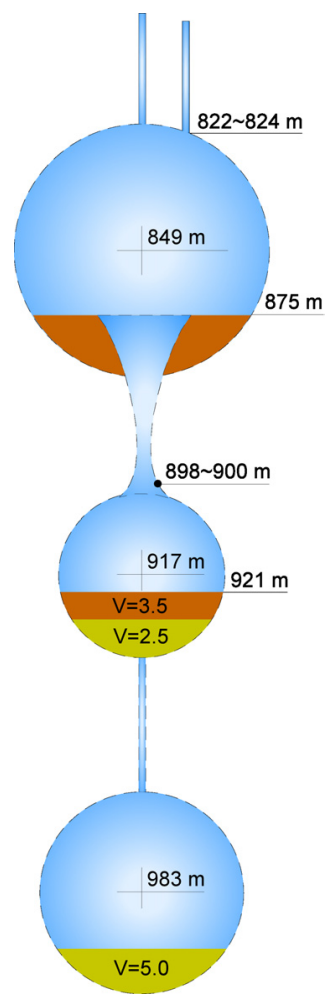

Figure 3: $\quad$ Cavity scheme at site A-XI. 


\section{Natural characteristics of AZGIR test site range}

Geographical features of the region are its relative closeness to the Volga River and the Caspian Sea. The described area is situated in the north-west of the Caspian Sea lowlands. The test site is placed in semi-desert area on a sandy edge in a large basin with a size of approximately $15 \mathrm{~km} \times 20 \mathrm{~km}$. In geomorphological relation, the region is presented by a series of sand massifs divided by loamy plains. The basin bottom, where the test site is located, consists of clay and heavy loams alternating in some places by low-powered deposits of sand. Atmospheric fallout is accumulated in low relief, these reservoirs are completely dry from June to September. Ground waters underlie depending upon the season, the relief and geological structure at a depth of $0.1-16 \mathrm{~m}$ from the surface. Soil cover of the territory is brown desert and salt soil. There is a definite differentiation on the genetic horizons: humus, carbonate, salt are characteristic of a brown soil profile. The thickness of the soil layer at the described area is insignificant $(2-6 \mathrm{~cm})$. The region's climate is strongly continental, arid; it is formed under the predominant influence of arctic, Iranian and Turan air mass. The average annual fallout is more than $200 \mathrm{~mm}$. The average annual air temperature is $7.3^{\circ} \mathrm{C}$. North (Summer) and East (Winter) parts steady wind at a speed of $15-20 \mathrm{~m} / \mathrm{s}$ and more are characterized for the region.

\section{Characteristic of radioactive contaminated areas at the site}

Site radiation control was carried out by a detailed method through ground survey on a grid $10 \mathrm{~m} \times 10 \mathrm{~m}$ (orthogonally related directions with distances in $10 \mathrm{~m}$ between them). At the surface of A-I, A-II, A-III, A-V and A-X sites radioactive contaminated $0.4-0.6 \mathrm{~m}^{2}$ areas (spots) are defined. These are the potential source of the second environment pollution. More contaminated sites are A-II and A-X, as by site quantity so by value of exposure (equivalent) dose rate (EDR), Figure 4. A-I, A-II, A-III, A-V and A-X sites in total amount of 200 spots are related to removal.

Soil samples selected from these spots were analyzed using alpha, beta and gamma-spectrometry methods. The following artificial radionuclides with specific activity: Am-241 up to $5.0 \mathrm{~Bq} / \mathrm{kg}$, Cs-137 up to $9000 \mathrm{~Bq} / \mathrm{kg}$, Sr-90 up to $17 \mathrm{~Bq} / \mathrm{kg}, \mathrm{Pu}-239+240$ up to $2.0 \mathrm{~Bq} / \mathrm{kg}$ were identified; under the Radiation Safety Standards of Kazakhstan, these soils are not related to the radioactive waste category but to disposal at general industrial waste storage. In addition, Cs-137 content soil can determine the overrunning of the maximum permissible public dose because its specific activity is close to the criterion for radioactive waste $\left(10^{4} \mathrm{~Bq} / \mathrm{kg}\right)$.

For the study of Cs-137 with soil particles degree of association the experiments on its leachability were carried out. Experiment results showed that no less than $95 \%$ Cs-137 was in linked form, which is not leachable with ammonium-acetated buffered solution [5]. 


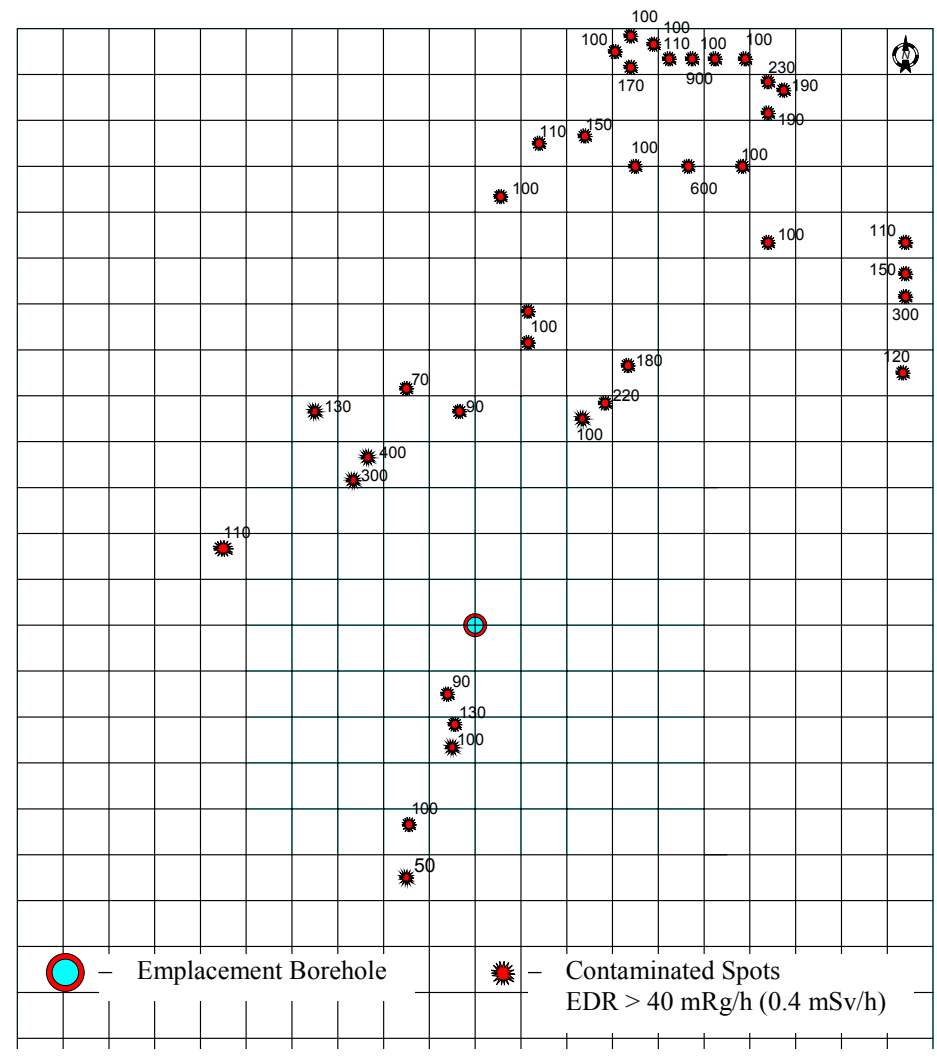

Figure 4: $\quad$ Radiation background at A-X site.

Even under infiltration waters, entry into the storage Cs-137 will not be leached by ground waters that exclude its further migration in solely unfavorable conditions.

Spots scheduled for elimination were located at topsoil. The total spot area does not exceed $90 \mathrm{~m}^{2}$. These are formed during the process of cavity opening, under radioactive ground recovering, sampling of salt solution and different technological operations execution. The organization operating the test site (Russia) temporarily placed all the mentioned contaminations in a trench within the site and buried it in cavities A-III and A-X [6]. Analyses of layer-by-layer samples from local spots showed that basic activity was focused in the upper 10 $15 \mathrm{~cm}$ layer. Besides, maximal concentrations are defined in soil layer $5-10 \mathrm{~cm}$, in comparison with $0-5 \mathrm{~cm}$ layer, from which the part of radionuclides was brought into the environment by the wind as well as the part that was washed by rain and melt waters. However, it is not possible to exclude the presence of radioactivity in more deep layers as excavation and re-disposal from the trench into cavity were carried out without proper quality controls. Consequently, soil cover was technologically damaged. 


\section{Elimination of hot spots}

The sample of radioactive soil was drawn by $5 \mathrm{~cm}$ layers at the bottom of the excavation at a level of 30 micro-roentgens per hour before the moment of fixing. In cases when EDR values were neither decreasing nor increasing, the soil sample ceased at a depth where the backfilling with clean soil with the $10 \mathrm{~cm}$ half-value layer made it possible to obtain EDR values in 30 micro-roentgens per hour on the daylight surface (Figure 5).

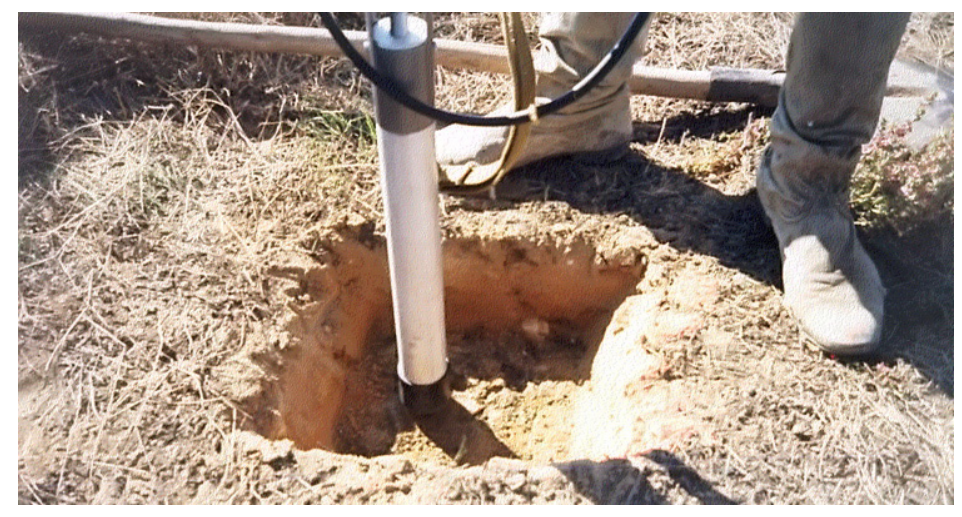

Figure 5: Dosimetry of pits.

Selected contaminated soil was intensively intermixed in special pans and than placed in a plastic sack. EDR was determined at the surface of each sack. Composited samples with high EDR were selected from the sack in order to determine the specific activity of Cs-137. Sacks were marked and data on the site index, position coordinates of soil sorting, EDR at the surface of sacks, volume and weight of soil from each radioactive spot was entered into the special log. Soil samples were transferred to the Institute of Nuclear Physics (Almaty city) where Cs-137 content was determined under laboratory conditions by meands of gamma-ray spectrometry.

Sacks with contaminated soil were tightly placed in a burial trench of the following size: (width $\times$ depth $\times$ length): $1 \mathrm{~m} \times 3 \mathrm{~m} \times 6 \mathrm{~m}$. After placing all sacks, the exposure dose rate was measured on the ground level under the open storage and also at the surface of all packed sacks. The trench was backfilled with clean soil which was excavated during the preparation of the storage, the thickness of the layer was about $1 \mathrm{~m}$ so that the Exposure Dose Rate (EDR) would not exceed 30 micro-roentgens per hour on the daylight surface. The trench coating was tamped and did not exceed $0.5 \mathrm{~m}$ from the daylight surface.

Reference pegs were located in storage nooks for switching of these points in plan of regular monitoring. After samples of radioactive soil and its disposal, newly formed excavations were filled with clean soil that was excavated from the trench and imported additionally. The backfilled soil did not exceed the relief of the site within limits of $10 \mathrm{~cm}$. The results of EDR measurement showed that 
the radiation situation in sites which had spots of radioactive contamination had significantly improved after taking some action on the decontamination of areas of sites. Values of EDR amounted to 900 micro-roentgens per hour before room works and they were between 20 to 30 micro-roentgens per hour after room works (Table 3).

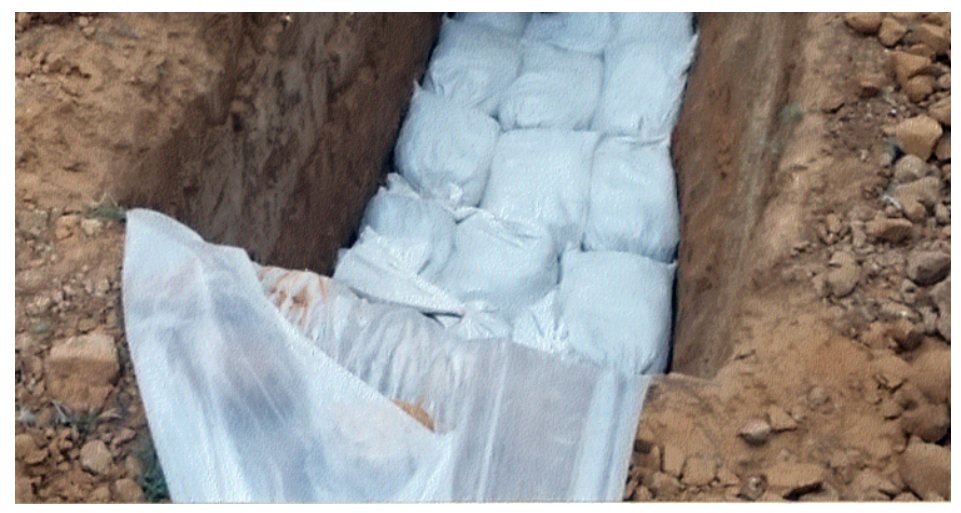

Figure 6: Depositing of radioactive soil in trench storage.

Table 3: Dosimetry in A-X site after cleansing, EDR $(m R / h)$.

\begin{tabular}{|c|c|c|c|c|c|c|c|c|c|c|c|}
\hline \multirow{2}{*}{\multicolumn{2}{|c|}{$\begin{array}{c}\begin{array}{c}\text { before } \\
\text { elimination }\end{array} \\
\text { April }\end{array}$}} & \multicolumn{2}{|c|}{$\begin{array}{c}\text { after } \\
\text { elimination }\end{array}$} & \multirow{2}{*}{\multicolumn{2}{|c|}{\begin{tabular}{|c|}
$\begin{array}{c}\text { before } \\
\text { elimination }\end{array}$ \\
April \\
\end{tabular}}} & \multicolumn{2}{|c|}{$\begin{array}{c}\text { after } \\
\text { elimination }\end{array}$} & \multirow{2}{*}{\multicolumn{2}{|c|}{\begin{tabular}{|c|}
$\begin{array}{c}\text { before } \\
\text { elimination }\end{array}$ \\
April \\
\end{tabular}}} & \multicolumn{2}{|c|}{\begin{tabular}{c|} 
after \\
elimination
\end{tabular}} \\
\hline & & July & August & & & \begin{tabular}{|l|l|} 
July \\
\end{tabular} & August & & & July & August \\
\hline $\begin{array}{l}\text { No of } \\
\text { points }\end{array}$ & EDR & EDR & EDR & $\begin{array}{l}\text { No of } \\
\text { points }\end{array}$ & EDR & EDR & EDR & \begin{tabular}{|l|} 
No of \\
points
\end{tabular} & EDR & EDR & EDR \\
\hline 1 & 100 & 25 & 25 & 9 & 400 & 30 & 30 & 17 & 150 & 31 & 30 \\
\hline 2 & 270 & 30 & 30 & 10 & 110 & 30 & 30 & 18 & 150 & 25 & 25 \\
\hline 3 & 280 & 25 & 30 & 11 & 100 & 31 & 30 & 19 & 120 & 30 & 26 \\
\hline 4 & 110 & 25 & 27 & 12 & 150 & 30 & 30 & 20 & 900 & 23 & 25 \\
\hline 5 & 170 & 30 & 30 & 13 & 130 & 32 & 32 & 21 & 100 & 27 & 24 \\
\hline 6 & 190 & 30 & 32 & 14 & 200 & 33 & 32 & 22 & 110 & 30 & 28 \\
\hline 7 & 110 & 30 & 30 & 15 & 170 & 30 & 31 & 23 & 100 & 23 & 25 \\
\hline 8 & 160 & 30 & 32 & 16 & 150 & 29 & 28 & 24 & 110 & 24 & 24 \\
\hline
\end{tabular}

\section{Conclusion}

The total weight of the excavated radioactive soil was $5060 \mathrm{~kg}$. The average concentration and total activity of Cs-137 in the removed soil was $5000 \mathrm{~Bq} / \mathrm{kg}$ and $3 \times 10^{7} \mathrm{~Bq}$. The research carried out and the engineering works on decontamination and the removal of radioactive contamination from the area of the Azgir test site made it possible to for the radiological situation at the test site and in surrounding areas to be improved. After performing the abandonment 
operations, danger to personnel and population from radiation doses which were previously over the safe rating values for radioactive soil contamination were excluded.

\section{References}

[1] S.A. Berezin, D.G. Gilmanov, Zh. R. Zhotabaev, K.K. Kadyrzhanov and others. NNC RK Bulletin, 3rd edition, 2001.

[2] A.S. Krivokhatsky and others. The main characteristics of radiation situation after completion of underground nuclear explosions in the interests of national economy in the salt- dome deposit land of Bolshoi Azgir (Kazakhstan). Preprint RI-223 SPA "Radium Institute", CSRIatominform, 1992.

[3] E.Z. Akhmetov, D.G. Gilmanov and others. AZGIR testing site. Preprint 1-96, Institute of Nuclear physics, Almaty, 1996.

[4] A.S. Krivohatsky and others. Radionuclide effects due to peaceful underground nuclear explosions in the salt deposit land of Bolshoi Azgir. CSRIatominform Bulletin, M, 1993, No 9.

[5] E.Z. Akhmetov et al. The granulometrical fractions of soil, distribution of Cesium-137 on its and the fastening of soil surface contaminated by radionuclides at locations of the "Azgir test site". International workshop. Effect of ionizing radiation on ecological situation of countries from Caucasian region and Caspian Sea basin. Azerbaijan, Baku, 2002, p. 92.

[6] Analysis and phased improvement of radiation situation near the object "Galit". Report of SPA "Radium Institute" .S-P, 1994.

[7] Suitability evaluation of places and facilities in Degelen and Azgir in the Republic of Kazakhstan as location for radioactive waste burial. Report No D -1/96, NNC RK fund, 1997.

[8] D.G. Gilmanov, E.Z. Akhmetov, J. Ziegenhagen and others. West Azgir Salt Dome as Massif for Locating Radioactive Waste Burial. NNC RK Bulletin, 1st edition, 2005. 